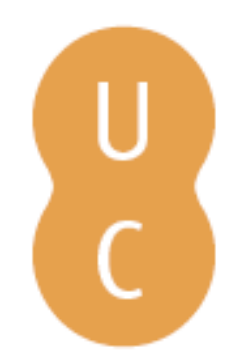

\title{
pompalina
}

\section{Adipocere formation in a river environment}

Autor(es): $\quad$ Notter, S. J.; Stuart, B. H.; Dent, B. B.; Langlois, N. Publicado por: Imprensa da Universidade de Coimbra; International Academy of Legal

URL

persistente: URI:http://hdl.handle.net/10316.2/31706

DOI: $\quad$ DOI:http://dx.doi.org/10.14195/978-989-26-0173-1_2

Accessed : $\quad$ 26-Apr-2023 15:34:28

A navegação consulta e descarregamento dos títulos inseridos nas Bibliotecas Digitais UC Digitalis, UC Pombalina e UC Impactum, pressupõem a aceitação plena e sem reservas dos Termos e Condições de Uso destas Bibliotecas Digitais, disponíveis em https://digitalis.uc.pt/pt-pt/termos.

Conforme exposto nos referidos Termos e Condições de Uso, o descarregamento de títulos de acesso restrito requer uma licença válida de autorização devendo o utilizador aceder ao(s) documento(s) a partir de um endereço de IP da instituição detentora da supramencionada licença.

Ao utilizador é apenas permitido o descarregamento para uso pessoal, pelo que o emprego do(s) título(s) descarregado(s) para outro fim, designadamente comercial, carece de autorização do respetivo autor ou editor da obra.

Na medida em que todas as obras da UC Digitalis se encontram protegidas pelo Código do Direito de Autor e Direitos Conexos e demais legislação aplicável, toda a cópia, parcial ou total, deste documento, nos casos em que é legalmente admitida, deverá conter ou fazer-se acompanhar por este aviso.

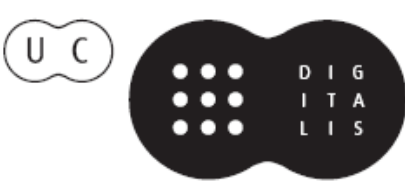




\section{Duarte Nuno Vieira Anthony Busuttil \\ Denis Cusack • Philip Beth}
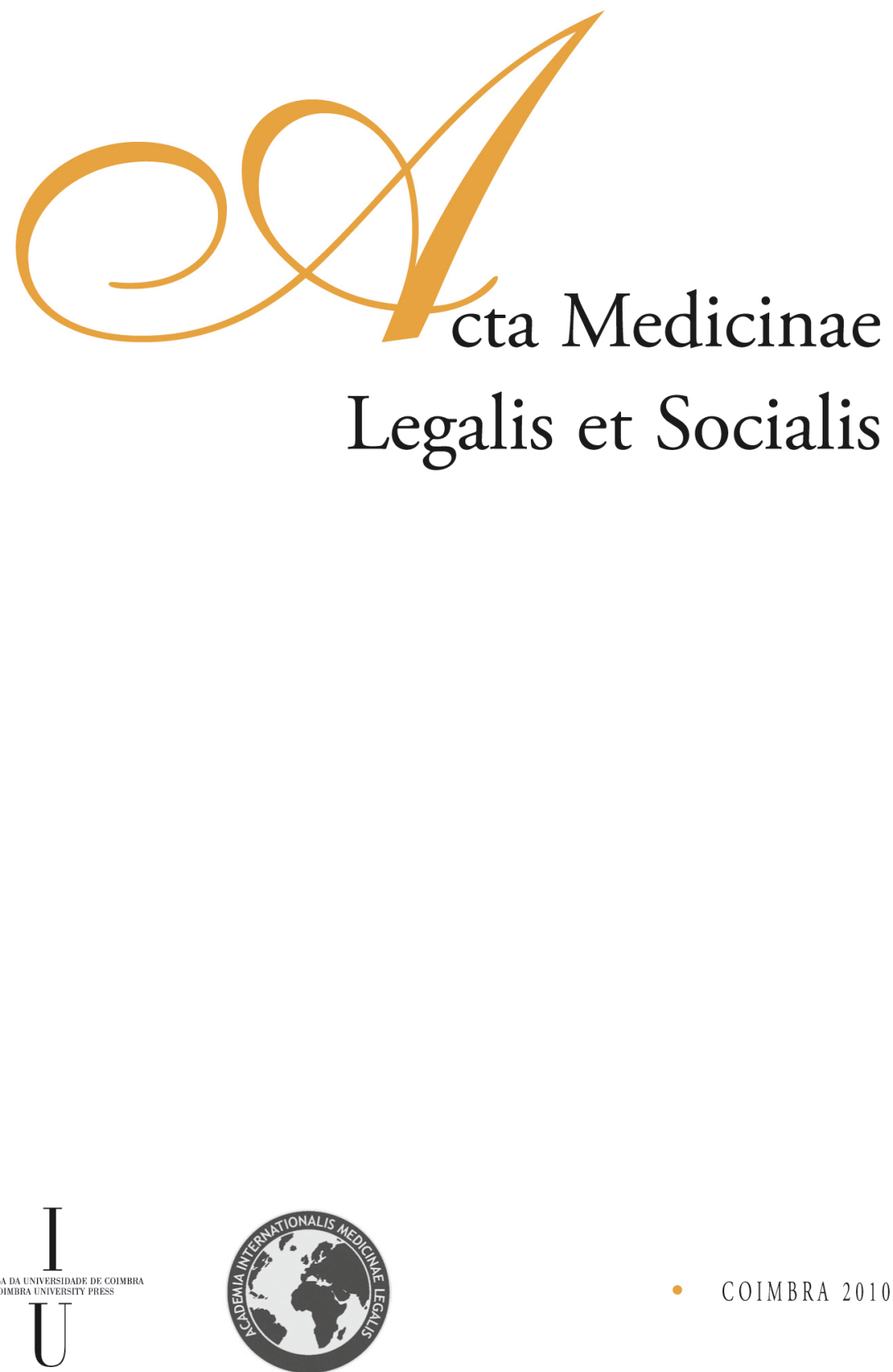
S. J. Notter ${ }^{1}$, B. H. Stuart ${ }^{1}$, B. B. Dent ${ }^{1}$, N. Langlois ${ }^{2}$

${ }^{1}$ Centre for Forensic Science, University of Technology, Sydney, Australia

${ }^{2}$ Forensic Science SA, Adelaide, Australia

\title{
ADIPOCERE FORMATION IN A RIVER ENVIRONMENT
}

\begin{abstract}
Adipocere is a late post-mortem decomposition product that consists of a mixture of fatty acids. The rate of formation of adipocere in a river water environment has been monitored. Adipocere formed from pig adipose tissue has been analysed using gas chromatography - mass spectrometry (GCMS) in order to determine the fatty acid composition, and hence, the degree of formation in the different environments. The study shows that the rate at which adipocere forms depends on the type of aqueous environment.
\end{abstract}

\section{Introduction}

Adipocere is a grey-white waxy substance that may be observed late post-mortem. The appearance of adipocere is of interest as it may slow the decomposition process or preserve human remains. Adipocere is observed in bodies found in aqueous environments and it is often noted that a moist environment is conducive to the formation of adipocere [1-4]. However, little work has been reported on the characterisation of adipocere formed in aqueous environments. An understanding of the composition of the adipocere formed can provide an indication of the extent of formation of this decomposition product and, thus, the effect of the aqueous environment on its formation.

Adipocere is mainly composed of a mixture of fatty acids, predominantly palmitic and stearic acids, as well as hydroxy fatty acids and salts of fatty acids [5-9]. Adipocere initially results from the conversion of adipose tissue into unsaturated fatty acids and then into saturated fatty acids. Previous studies have involved the analysis of the composition of adipocere formed in soil environments and demonstrated that the formation may be monitored by analysing the fatty acid composition of adipocere [1014]. Gas chromatography - mass spectrometry (GCMS) has been utilised to identify the fatty acids present in adipocere. More recently, a modified GCMS method has been successfully employed to analyse samples formed in aqueous environments [15].

In the present study, an investigation into the formation of adipocere in pig tissue in a river environment has been carried out. GCMS was employed to determine the fatty acid composition, and hence, the degree of formation of each adipocere sample. 


\section{Materials and methods}

Adipose tissue from pigs (Sus scrofa) was obtained from a retail butcher. A $10 \mathrm{~cm}$ $\mathrm{x} 10 \mathrm{~cm}$ piece of tissue collected from the abdominal region containing muscle and skin was used for each experiment.

For the laboratory model studies, $5 \mathrm{~L}$ high density polyethylene sealed containers were used. The containers were acid-washed with $5 \% \mathrm{v} / \mathrm{v}$ nitric acid, rinsed with distilled water and air dried. A basket of low density polyethylene was constructed to contain the adipose tissue and was suspended from the lid of the container to surround the tissue by solution. Three replicates of each set-up were prepared and stored at $20^{\circ} \mathrm{C} .1 \mathrm{~g}$ of pig faecal material was smeared onto the skin surface of the tissue to ensure the necessary bacteria to promote putrefaction. Samples of pig adipocere were collected from random sections of the tissue over a period of 18 months at 3 monthly intervals. The collected samples were placed in sealed specimen containers, homogenised and stored at $-18^{\circ} \mathrm{C}$ until analysis.

The field study site was a freshwater river located in Laggan, New South Wales, Australia. The sampling containers were similar to the model adipocere containers, but holes of approximately $0.5 \mathrm{~cm}$ in diameter were inserted throughout the surface and weight added to maintain submersion. The containers were covered in netting to exclude animals and the containers were secured to posts on the riverbank (Figures 1 and 2). Five repeats were created, which were spaced at regular intervals at the site. The containers were placed in the deepest parts of the river to ensure the containers were submerged for the entire sampling period. Samples were collected from the field trial over 18 months at 3 monthly intervals. The river laboratory model used water obtained from the field site.

For analysis, $5 \mathrm{mg}$ of each adipocere sample was placed in $5 \mathrm{ml}$ hexane, sonicated for two $10 \mathrm{~min}$ sessions and centrifuged $(2500 \mathrm{rpm}, 5 \mathrm{~min})$. The supernatant was aspirated and frozen until analysis. The samples were analysed using GCMS according to the procedure detailed by Notter et al. [15]. The fatty acids examined were myristic, palmitoleic, palmitic, linoleic, oleic, stearic and 10-hydroxy stearic acids.

\section{Results and discussion}

In order to observe any trends in the data, the ratios of the concentrations of the unsaturated (palmitoleic, linoleic, oleic acids) to saturated (myristic, palmitic, stearic, 10-hydroxy stearic acids) fatty acids were determined for each sample using GCMS. From such a ratio, an estimation of the stage of formation of adipocere can be made. An earlier investigation divided the process of adipocere formation into three stages based on the average \% of saturated fatty acids present: early (40-60\%), intermediate (70-90\%) and advanced (>90\%) [16]. The estimated unsaturated / saturated fatty acid concentration ratio for each stage used in this study was: early (1.17), intermediate (0.15) and advanced (0.05).

Figure 3 shows the fatty acid ratios for each collected specimen at the different sampling intervals. Inspection of the control values shows that the fatty acid ratio decreases with time and even at 3 months, the adipocere is in an intermediate stage of formation. A comparison of the control values with those of the model river system reveals that the decrease in ratio occurs earlier in the river water used, indicating that 
adipocere is forming faster in the river water. The pig tissue placed in the field shows an even lower fatty acid ratio value at each sampling time than those determined for both the control and the model river systems. Thus, the adipocere formed by the pig adipose tissue forms faster in the field compared to the laboratory model systems.

As adipocere forms more readily in the river water, either in the laboratory model or in the field, there is the possibility that certain species contained in the river water may be responsible for the more advanced formation. Although a detailed chemical analysis of the river water used for these experiments is yet to be undertaken, such analyses should provide some insight into the mechanism of adipocere formation in river water. Other work carried out in our laboratory on model systems involving the presence of different cationic species and the modification of $\mathrm{pH}$ have indicated that these factors affect the rate of adipocere formation. The details of these studies will be reported in upcoming publications.

The notable increase in adipocere in the flowing river system compared to the still laboratory model system is significant. A possible explanation for the rate difference could be the removal of other decomposition products (e.g. glycerol) by the flowing environment. Such an action may disrupt other decomposition processes and so may allow the process of adipocere formation to more readily occur.

\section{Conclusions}

A study has been made of the rate of formation of adipocere for pig adipose tissue in river water environments. It has been demonstrated that adipocere forms faster in river water, in both model and field studies, compared to a control in distilled water. The natural flowing river system is also responsible for a more rapid formation of this decomposition product. Further work is being undertaken into the species present in the river water that may be responsible for the increased formation rate, as well as into the significance of the movement of the water.

\section{References}

[1] AK MANT, R FURBANK, Adipocere - a review, J. Forensic Med., 4, 18-35, 1957.

[2] JD DIX, Missouri's Lakes and the disposal of homicide victims, J. Forensic Sci. 32, 806-809, 1987.

[3] K TOMITA, On the production of hydroxy fatty acids and fatty acid oligomers in the course of adipocere formation, Jap. J. Legal Med., 38, 257-72, 1984.

[4] TG O'BRIEN, AC KUEHNER, Waxing grave about adipocere: soft tissue change in an aquatic context, J. Forensic Sci. 52, 294-301, 2007.

[5] H GILL-KING, Chemical and ultrastructural aspects of decomposition, in Forensic Taphonomy: The Postmortem Fate of Human Remains, Boca Raton, CRC Press, 1999.

[6] T TAKATORI, K TERAZAWA, K NAKANO, H MATSUMIYA, Identification of 10-hydroxy12-octadecenoic acid in adipocere, Forensic Sci. Int., 23, 117-122, 1983.

[7] T TAKATORI, Investigations on the mechanism of adipocere formation and its relation to other biochemical reactions, Forensic Sci. Int., 80, 49-61, 1996. 
[8] T BEREUTER, E LORBEER, C REITER, H UNTERDORFER, Post-mortem alterations of human lipids. Part I: Evaluation of adipocere formation and mummification by desiccation, in Human Mummies: A Global Survey of Their Status and The Techniques of Conservation, Wien, Springer-Verlag, 1996.

[9] F YAN, R MCNALLY, EJ KONTANIS, OA SADIK, Preliminary quantitative investigation of postmortem adipocere formation, J. Forensic Sci., 46, 609-614, 2001.

[10] SL FORBES, BH STUART, BB DENT, SF MULCAHY, Characterisation of adipocere formation in animal species, J. Forensic Sci., 50, 633-640, 2005.

[11] SL FORBES, J KEEGAN, BH STUART, BB DENT, A gas chromatography-mass spectrometry method for the detection of adipocere in grave soils, Eur. J. Lipid Sci. Tech., 105, 761-768, 2003.

[12] SL FORBES, BB DENT, BH STUART, The effect of soil type on adipocere formation, Forensic Sci. Int., 154, 35-43, 2005.

[13] SL FORBES, BH STUART, BB DENT, The effect of the method of burial on adipocere formation, Forensic Sci. Int., 154, 44-52, 2005.

[14] SL FORBES, BH STUART, BB DENT, The effect of the burial environment on adipocere formation, Forensic Sci. Int., 154, 24-34, 2005.

[15] SJ NOTTER, BH STUART, BB DENT, J KEEGAN, Solid-phase extraction in combination with GCMS for the quantification of free fatty acids in adipocere, Eur. J. Lipid Sci. Tech., 110, 73-80, 2008.

[16] S FORBES, An investigation of the factors affecting the formation of adipocere in grave soils, PhD Thesis, University of Technology, Sydney, 2003.

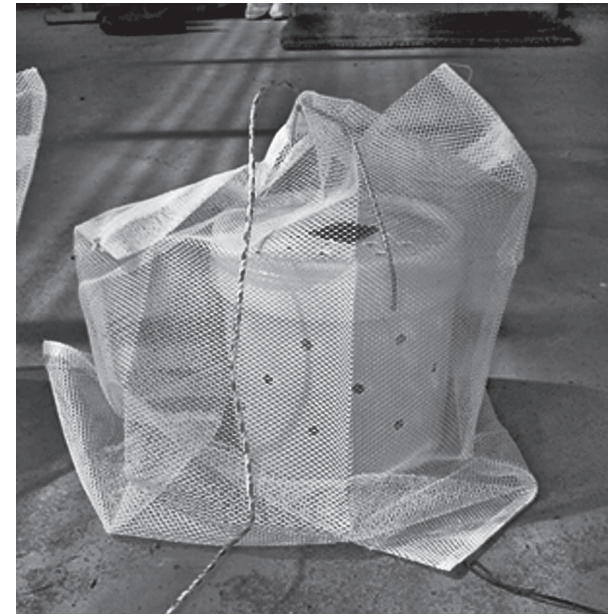

Figure 1 - Field study container.

\begin{tabular}{|llll|}
\hline sampling time $/$ months & control & model river & field river \\
\hline 3 & 0.15 & 0.14 & \\
6 & 0.15 & 0.07 & 0.04 \\
9 & 0.05 & 0.01 & 0.03 \\
12 & 0.06 & 0.01 & 0.01 \\
15 & 0.05 & 0.01 & 0.01 \\
18 & 0.03 & 0.00 & 0.01 \\
\hline
\end{tabular}

Figure 3 - Unsaturated / saturated fatty acid concentration ratios for pig adipocere.

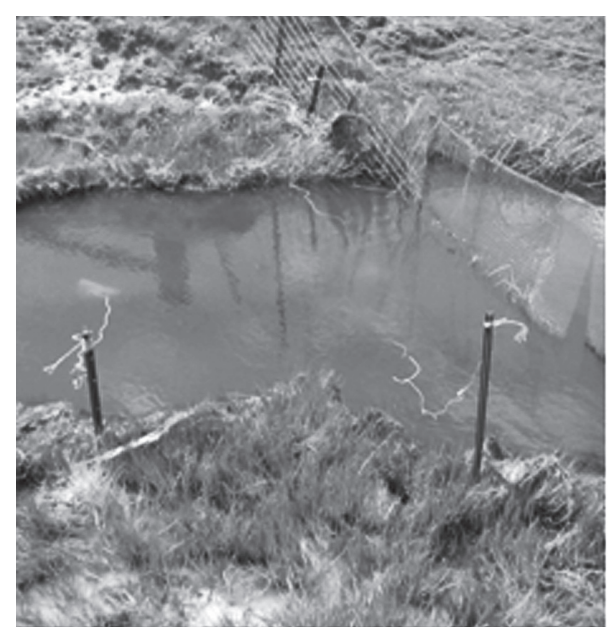

Figure 2 - Placement of field study containers. 